DOI https://doi.org/10.30525/978-9934-588-91-4-12

\title{
ДО ПИТАННЯ ВИКЛАДАННЯ ІСТОРИЧНИХ ДИСЦИПЛІН В СУЧАСНИХ ЗАКЛАДАХ ВИЩОЇ ОСВІТИ УКРАЇНИ
}

\author{
Коротенко Д. В. \\ кандидат історичних наук, \\ доцент кафедри соціально-гуманітарних дисичиплін \\ Дніпропетровської академї музики імені Михайла Глінки \\ м. Дніпро, Україна
}

Викладанню історичних дисциплін у закладах вищої освіти України (далі - ЗВО) присвячена низка праць сучасних українських дослідників. Зокрема, Я.Мотенко та Є.Шишкіна зазначали, що пріоритетними тенденціями у вищій освіті України лишається інтеграція навчальних дисциплін та економічний прагматизм [1, с. 137]. Проте чи не важливішою за них $є$ консолідаційна функція освіти, що випливає 3 об'єктивних умов розвитку сучасної України, зокрема значних регіональних відмінностей, що проявляються стосовно історичної пам'яті.

Проблеми викладання гуманітарних дисциплін, в тому числі історії, у вищій школі усвідомлюються і керівництвом МОНУ. Ще у 2009 р. очільник міністерства I. Вакарчук запропонував замінити курс «історії України» курсом «Історія української культури». Це мало б зробити освітню траєкторію студента більш гнучкою, уникнути дублювання зі шкільним курсом, продемонструвати контекст, тобто зв'язки української культури з європейською та світовою [2, с. 158]. Тоді ж прозвучала i аргументація на захист традиційного курсу історії України, що в основному перебуває на озброєнні противників змін у цій царині і дотепер. Зокрема, освітяни вказували на вікові обмеження, які не дозволяють розкрити повною мірою складність і суперечливість історичного процесу у шкільному курсі. Також підкреслювалося, що «академічному» курсу властивий проблемно-концептуальний підхід, засвоєння не фактів, а інтерпретацій, формування світоглядних концепцій.

Ця дискусія призвела до появи значного розмаїття навчальних дисциплін 3 історичним наповненням: «Історія України», «Історія та культура України», «Історія української культури», «Українська культура в контексті світової» тощо. Проте слід констатувати, що це не призвело до відчутних змін у методиці викладання історії у вищій школі, й жаданої трансформації змістовного наповнення згаданих курсів.

Поява двох дисциплін історичного спрямування, як це практикувалося останнім часом, призвела до того, що вони дублювали один одного, адже не можна говорити про культуру, не згадуючи історичний контекст. Інтегрований курс «Історія та культура України» був позбав- 
лений цього недоліку, проте так само перевантажений фактичним матеріалом, який студенти мали засвоїти у досить стислі терміни. Слід зазначити, що історія України на рівні як середньої, так і вищої школи ще несе на собі відбиток перехідного пострадянського періоду, коли ключовим було подолання радянської історіографічної традиції i заповнення «білих плям» історії України. Відзначимо також консерватизм й обмежений у часі курс історії України для нефахівців, де результати новітніх досліджень практично не впливають на зміст, адже основна увага приділена фактологічній складовій.

Постає питання: для чого взагалі ми вивчаємо історію у вищій школі? На нашу думку, вкрай необхідним вбачається перехід від суб'єкт-об'єктної до суб'єкт-суб'єктної моделі навчання. Активна взаємодія викладача зі студентами із дискусійних питань має стати ключовою відмінністю від шкільного курсу, де першочерговим завданням лишається засвоєння певної суми знань. Важливо також встановлювати зв'язки історичних подій та процесів із сучасністю, показувати їх матеріальні, культурні, духовні наслідки і прояви в українському сьогоденні.

Власне, ми вбачаємо «Історію України» та всі похідні дисципліни - теоретично-прикладними, проблемними. Так, проблемний підхід мусить широко застосовуватися, причому, висновки мають не нав'язуватися, а формулюватися спільно студентами й викладачем на основі широкої джерельної бази. Історія у вищій школі мусить обростати міждисциплінарними зв'язками, що проявляється у використанні студентами історичних знань на практиці й у своїй професійній діяльності.

Крім того, слід зазначити, що на сьогодні перед молодими людьми, студентством стоять нові завдання, пов'язані з формуванням громадянського соціуму, де відповідальність кожної особи перед державою, громадою та місцевим самоврядуванням зростає врази. Можливо, вже слід почати дійсно готувати студента до відповідального дорослого життя, розглядаючи не стільки теоретичні засади формування нового українського суспільства, але й формуючи практичні вміння та навички, що допомагають розвинути активну громадянську позицію.

Так, в Дніпропетровській академії музики ім. М.Глінки нами апробується новий авторський курс «Україна: історія та сучасність» (авторка-розробниця - Коротенко Д.В.), суть якого спрямована на формування відкритої свідомості студентів ЗВО. Актуальність курсу зумовлена новими викликами, що стоять перед українською молоддю сьогодні: формування ойкумени для життя та розвитку, становлення української держави, розуміння свого місця і ролі в українському соціумі. Метою курсу $\epsilon$ аналіз та розуміння державотворчих, етнокультурних та духовних засад розвитку українського суспільства та використання на практиці отриманих знань. 
Так, кожна лекція дисципліни «Україна: історія та сучасність» присвячена певній історичній проблемі й поділяється на три складові: «Історія України», «Сучасність України», а також «Дискусійний блок» У блоці «Історія» відбувається екскурс в проблему, формується розуміння тих процесів, які вплинули на сучасне становище України, висвітлюються ключові політичні, суспільні події та явища минулого. Блок «Сучасність» передбачає розгляд певної проблеми, якій присвячена лекція, на даному етапі розвитку, починаючи з 1991 року. Дискусійний блок передбачає обговорення та практичні висновки із запропонованих питань в ході лекцій, практичних та самостійних занять. Це здійснюється шляхом активізації розумової діяльності, знаходження причин проблем та траєкторій їх вирішення. Таким чином, студент може не тільки ставити й розуміти проблему в історичній ретроспективі, але й знаходити причинно-наслідкові зв'язки, думати над власним бачення розв'язання питання, про що пише власне есе-роздум як домашнє завдання.

Запропонований нами підхід до вивчення історії України допомагає розвитку аналітичного мислення, формує вміння висловлювати власну думку, спираючись на факти, бачити нестандартні рішення та здатність конкретної особистості впливати на події при формуванні буття українського соціуму.

Крім того, студентам пропонуються «кейси» до кожної лекції $з$ допоміжними матеріалами (документальна база, наративні та навчальні матеріали 3 певної проблематики) та наочні матеріали (презентації та роздатковий матеріал).

Історія, як дисципліна у ЗВО повинна спиратися на ті суспільнополітичні реалії, в яких Україна наразі перебуває. Важливо під різними кутами висвітлити не шаблонну «історію», «культуру», «державотворення» тощо, а допомогти сучасній молоді (студентству) в практичному застосуванні отриманих під час навчання у школі знань. Таким чином формується комплексне сприйняття студентами історії України i забезпечується їх активна участь у суспільно-громадянському житті сучасної української держави.

\section{Література:}

1. Мотенко Я.В., Шишкіна С.К. Історична освіта у вищій школі як консолідуючий чинник українського суспільства. Украӥнознавчий альманах. Вип. 23. С. 136-141.

2. Мотенко Я.В., Шишкіна Є.К. Історичні дисципліни як складова вищої освіти в Україні на початку XXI ст. Історичні студї суспільного прогресу. 2018. № 6. С. 158-163.

3. Про затвердження Концепції національного виховання студентської молоді: рішення Колегії Міністерства освіти і науки України. 
Київ, 2009. URL: http://ru.osvita.ua/legislation/Vishya_osvita/4310/ (дата звернення: 27.10.2020).

4. Про затвердження Концепції національно-патріотичного виховання дітей і молоді, Заходів щодо реалізації Концепції національнопатріотичного виховання дітей і молоді та методичних рекомендацій щодо національно-патріотичного виховання у загальноосвітніх навчальних закладах. Київ, 2015. URL: https://zakon.rada.gov.ua/ rada/show/v0641729-15\#Техt (дата звернення: 27.10.2020).

5. Солошенко О. Використання методики ресурсно-орієнтованого навчання при викладанні дисциплін гуманітарного циклу: теоретичний аспект. Новий Колегіум. 2018. № 3. С. 62-67.

DOI https://doi.org/10.30525/978-9934-588-91-4-13

\title{
«ЧЕРНИГОВСКИЙ АДРЕС» 1879 РОКУ \\ ЯК УНІКАЛЬНЕ ДЖЕРЕЛО 3 ІСТОРІЇ ПОЛІТИЧНОӤ ДІЯЛЬНОСТІ І. І. ПЕТРУНКЕВИЧА В УКРАЇНІ (70 РР. ХІХ СТ.)
}

\author{
Котельницький Н. А. \\ кандидат історичних наук, \\ член-кореспондент \\ Центру украӥнських досліджень Інституту Європи РАН \\ м. Чернігів, Україна
}

Життя та широкомасштабна діяльність в Україні засновника, «патріарха» та безсумнівного лідера земського ліберального руху у Російській імперії - Івана Ілліча Петрункевича (1843-1928), були позначені дуже яскравими політичними подіями, які отримали великий суспільний резонанс у державі у силу свого «одіозного» характеру. Без усіляких перебільшень, до згаданих подій можна віднести і колосальний політичний скандал у Чернігівському губернському земському зібранні, який виник у січні 1879 р. навколо підготовленої спеціальною комісією губернського земства офіційної відповіді російському імператору Олександру II та Уряду, які звернулись за допомогою до суспільства з закликом допомогти у боротьбі з революційним терором у країні. Історія підготовки, подання та політичного результату розгляду офіційної земської відповіді, що отримала назву - «Адрес Черниговского земства» достатньо відомі в історичній науці, тому вважаємо можливим не акцентувати на цьому увагу [1, p. 155-165].

Однак, оскільки текст принципово важливого документу, по суті, так і не був офіційно опублікований у Російській імперії згідно наказу 